JEL: M11, M21, 031

Bojan D. Krstić ${ }^{2}$

DOI: 10.5937/industrija43-9068

UDC: 005.42

005.216 .1

Original Scientific Paper

\title{
The Effects of Business Process Management on Improvement of Firm Performances
}

\author{
Article history: \\ Received: 15 September 2015 \\ Sent for revision: 12 October 2015 \\ Received in revised form: 7 December 2015 \\ Accepted: 8 December 2015 \\ Available online:30 December 2015
}

Abstract: The main purpose of this paper is to explore the acceptance of the business process orientation (BPO) in management practice of Serbian companies. The paper investigates the effects of business process management (BPM) on organizational performances. The empirical research was conducted on a sample of 120 enterprises by interviewing the managers, identifying their opinions and practices for the period 2012-2014. The research results demonstrate that the BPM elements have a positive influence on the performances of business processes. The obtained results are very useful for managers in Serbia, since they point out the relevance of more consistent application of business process management concept in day-to-day business activities with the aim of effective decision-making.

Keywords: business process management, organizational performance.

\section{Uticaj upravljanja poslovnim procesima na unapređenje performansi preduzeća}

Apstrakt: Glavni cilj ovog rada je da istraži stepen prihvatanja procesne orijentacije u upravljčkoj praksi preduzeća u Srbiji. U radu se istražuju efekti upravljanja poslovnim procesima na organizacione performanse. Empirijsko istraživanje je sprovedeno na uzorku od 120 preduzeća putem anketiranja menadžera, prikupljajući njihova mišljenja i poslovnu praksu za period 2012 2014. Rezultati istraživanja su pokazali da elementi upravljanja poslovnim procesima imaju pozitivan uticaj na performanse poslovnih procesa. Dobijeni

\footnotetext{
${ }^{1}$ State University of Novi Pazar, Department of Economic Sciences, ekahrovic@np.ac.rs

${ }^{2}$ University of Niš, Faculty of Economics
} 
Kahrović I.E., Krstić D.B.: The Effects of Business Process Management on...

podaci su vrlo korisni za menadžere u Srbiji, jer oni naglašavaju potrebu za većom primenom procesnog pristupa u upravljanju u svakodnevnim poslovnim aktivnostima i efektivnom donošenju odluka.

Ključne reči: upravljanje poslovnim procesima, organizacione perfomanse.

\section{Introduction}

The biggest challenges for organizations today and tomorrow are uncertainty of the globalized business environment, technology development, the complexity of business activity, information overload, strategic thinking and problem solving, etc. In response to the mentioned challenges, organizations are forced to innovate faster their business models and have to concentrate on competitors, customers and business processes. These new models have been defined as "business process orientation". This orientation implies that attention is placed on the business process as opposed to emphasizing organization's hierarchical and functional structure. A business process is a coordinated and measurable set of logically related tasks or activities that use inputs and produce appropriate outputs. In other words, business process is a precise sequence of organizational activities beyond time and place, with its beginning and end, and with determined inputs and outputs.

The process orientation assumes the management of a company as a series of interrelated business processes, which focuses on internal users and external customer demand satisfaction. It is essential that a particular enterprise and its management must focus on a continuous, day-to-day, and incremental performance improvement of various business processes, and performances of their integral elements, such as activities within a process and operations within an activity. Despite the fact that the meanings of the business process orientation differ, we accept the McCormack and Johnson (2001) definitions of process orientation: An organization that emphasizes process as opposed to hierarchies, a process oriented way of thinking, outcomes and customers (McCormack \& Johnson, 2001, p. 37).

The aim of this paper is to explore the acceptance of the business process orientation and BPM elements in practice of Serbian companies and investigate the possible impact of process acceptance, process management and measurement, and process organizational design on performances of business processes. This paper is structured into following three segments. The first part presents theoretical aspects and relevant literature review of the process management approach, firm performance and the correlation between the two concepts. In the second segment of the paper the authors present the research methodology, characteristics of the research sample, and the hypotheses. The third segment of the paper explains the research results and discussions, as well 
Kahrović I.E., Krstić D.B.: The Effects of Business Process Management on...

as concluding remarks about the confirmation or rejection of the initial hypotheses.

\section{Theoretical background and literature review}

Developing new models of the organization requires a new form of thinking, which will result in radical improvements of business performance. This new way has been typically described as business process orientation (BPO). Business process orientation was recommended thirty years ago by Michael Porter (1985). This author introduced the concept of interoperability across the value chain and horizontal organization as a significant topic within firms (Porter, 1985). Davenport and Short (1990) also depicted a process orientation within a company as a crucial component for success in "New Industrial Engineering: Information Technology and Business Process Redesign." They defined a process orientation as a horizontal design of business that cuts across the organization with product inputs at the beginning and outputs and customers at the end. They suggested that five major steps in process redesign are: developing the business vision and process objectives, identifying the processes to be redesigned, understanding and measuring the performance of existing processes, identifying IT levers, designing and prototype process (Davenport \& Short, 1990).

Furthermore, Hammer and Champy (1993) presented the BPO concept as a vital element of a successful reengineering effort in the most influential business management book "Reengineering the Corporation: A Manifesto for Business Revolution." They offered reengineering as a strategy to overcome the problematic cross-functional activities that present major performance issues to firms. The apparent conflict between a functional focus ("whom I report to") vs. a horizontal focus ("whom I provide value to") is offered by them as being brought back in balance by adding a BPO to the organization (Hammer \& Champy, 1993). Along with Hammer and Champy, Bryne (1993) among the first popularized the term "horizontal organization" and provided a prescriptive definition of a business process-oriented model. Numerous authors have researched the idea of organizing around business processes in a certain manner (Stalk \& Black, 1994; Dutta \& Manzoni, 1999; Ostroff, 1999; Galbraith, 2002; Gardner, 2004; Crosetto \& Macazaga, 2005; Harrington, 2006; Weske, 2012).

There are also numerous clarifications of process orientation and its basic elements. In depth literature review revels that various terms are being used to describe these management techniques. A process oriented organization is likewise regularly referred to as a "process centred organization" (Hammer, 1996), "horizontal organization" (Ostroff, 1999), "process enterprise" (Hammer \& Stanton, 1999), "process focused organization" (Gardner, 2004), "process managed organization" (Rummler, Ramias \& Rummler, 2006). In order to define 
Kahrović I.E., Krstić D.B.: The Effects of Business Process Management on...

the basic elements of business process orientation, it was necessary to conduct depth evaluation of previous researches (Table 1 ).

Table 1. Survey of various elements of business process orientation in an enterprise

\begin{tabular}{|c|c|c|c|c|c|c|c|c|}
\hline & 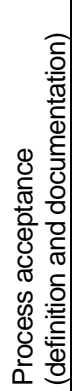 & 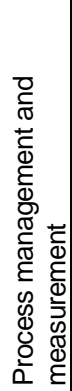 & 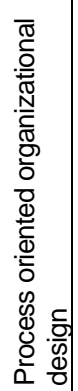 & 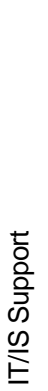 & 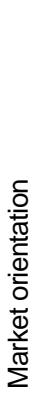 & 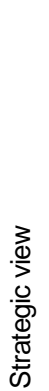 & 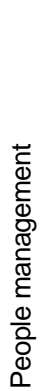 & $\begin{array}{l}\frac{3}{0} \\
\frac{0}{2} \\
\frac{0}{0} \\
\frac{0}{3} \\
0\end{array}$ \\
\hline Hammer \& Champy, 1993. & * & * & * & * & & * & & \\
\hline Davenport, 1993. & * & * & * & * & * & & & \\
\hline Byrne, 1993. & * & * & * & & * & & * & * \\
\hline Stalk Jr \& Black, 1994. & * & * & * & & * & & & * \\
\hline Sung \& Gibson, 1998. & * & * & * & * & * & * & * & \\
\hline Ostroff, 1999. & * & * & * & * & * & & * & * \\
\hline McCormack \& Johnson, 2001. & * & * & * & & & & & \\
\hline Galbraight, 2002. & * & & * & & & * & * & \\
\hline Reijers, 2006. & * & * & * & * & * & & & \\
\hline Hammer, 2007. & * & * & * & * & & & & \\
\hline Spanyi, 2007. & * & & * & & & * & * & \\
\hline Daft, 2007. & * & * & * & & * & & * & \\
\hline Bosilj, Hernaus, \& Kovačić, 2008. & * & * & * & * & * & & * & \\
\hline Neubauer, 2009. & * & * & * & * & & * & & \\
\hline Kohlbacher \& Gruenwald, 2011. & * & * & * & * & * & * & * & \\
\hline
\end{tabular}

Our examination demonstrated that there is a positive agreement for some of the constituents of BPO as the vast majority of the organizations appear to incorporate them, such as a) process acceptance (documentation and definition), b) process management and measurement, and c) process oriented organizational design.

Process acceptance. Comprehension of business processes is an imperative of BPO. Firms need to understand how processes operate, where they are being executed and how they interoperate. Kohlbacher (2008) cites the specified aspects of process acceptance that an organization must provide: existence of a complete and uniform enterprise process model, documentation of processes, 
Kahrović I.E., Krstić D.B.: The Effects of Business Process Management on...

definition of inputs and outputs for each process, definition of suppliers and customers for each process, existence of process cascades (internal customer supplier relationships between processes), segmentation of business processes if they face heterogeneous requirements.

Process management and measurement. Management and measurement are closely connected. The nonappearance of measurement constrains the organization's ability to analyze the impacts of changes, which inhibits systematic changes (Tenner \& DeToro, 1997). Kuwaiti and Kay (2000) have shown that performance measurement is a condition for process redesign as it enables the alignment of the organization's processes and strategy. Similarly, Neely (1999) argues that appropriate performance indicators encourage employees to act in alignment with the strategic goals.

Process oriented organizational design. As can be seen from the table 1, organizational design is one of components consistently viewed as key. Organizational structure portrayed the predominating configuration of activities and tasks in the company (Skivington \& Daft, 1991). Surely, hierarchal and functional organizational structure is not relevant for process orientation. Some of the most referred aspects of process oriented structure are (Davenport, 1993; Hammer \& Champy, 1993; Harmon, 2003; Kohlbacher, 2008; McCormack \& Johnson, 2001; Neubauer, 2009; Ostroff, 1999 and many others): organizing work around the core processes, process ownership, teamwork, flatter organizational structure, jobs that involve different task and activities, employee empowerment.

Business processes can be classified in several ways. Keen (1997) suggests that relevant processes are those that create value, processes that provide options and processes that sustain the value. Following Harmon (2005), the crucial business processes are the following: core processes, enabling processes, and managerial processes. Also, the process classification framework has been developed by the APQC International Benchmarking Clearinghouse. In that classification, operating processes are: understanding markets \& customer, develop vision \& strategy, design products \& services, market \& sell, produce \& deliver for manufacturing/service organization and invoice \& service customer. Management \& support processes are: develop and manage human resources, manage information, manage financial and physical resources, executive environmental management program, manage external relationships and manage improvement and change (APQC, 2008). The authors of this research, differentiate the following five business processes like important: the process of supplying necessary inputs $\left(P_{1}\right)$, the process of creation and manufacturing of products $\left(P_{2}\right)$, the process of selling products and accompanying marketing activities $\left(P_{3}\right)$, the process of product/service delivery $\left(P_{4}\right)$, and the process of providing after-sales services to customers $\left(P_{5}\right)$. 
Kahrović I.E., Krstić D.B.: The Effects of Business Process Management on...

Literature on business process orientation proposes that firms can enhance their overall performance by adopting a process perspective of business. The advantages that BPO conveys to organizations are various. It influences the soft side of firms as well as the quantitative performance. Some of the advantages reported in the literature are: cost savings through a more efficient execution of activities, improved customer focus, better integration across the organization, increased flexibility of the firm, reduced cycle times, elimination of unnecessary and replicated activities.

McCormack and Johnson (2001) have conducted one of the most influential studies in the field of business process orientation. They conducted an empirical study to investigate the correlation between BPO and improved business performance. Empirical findings of Kohlbacher and Reijers (2013) suggest that process performance measurement, a process-oriented organizational structure, the application of continuous process improvement methods, and a culture that is in line with a process management approach, are significantly and positively associated with organizational performance.

Škrinjar, Bosilj-Vukšić and Indihar-Štemberger (2008) conducted an empirical study of a model to test if higher levels of business process management convey to better firm performance. Namely, a joint empirical research by the Faculty of Economics in Ljubljana and Faculty of Economics in Zagreb explores the understanding of the process maturity level and the process view of Slovenian and Croatian organizations and to test the impact of a process orientation maturity level on firm performance. Hernaus et al. (2012) conducted empirical research, which suggests that process performance measurement practices provide better business results when aligned with business strategy and strategic importance to business process management.

\section{Research methodology}

\subsection{Aim and Hypotheses}

Empirical research was conducted on a sample of 120 companies operating in Serbia. The questionnaire was structured in such manner so that the key elements of process orientation in Serbian companies can be analyzed. The importance and actuality of this research is confirmed by the fact that this topic remains in focus of the management in most companies. Questionnaires were handed out to the management of companies, with the aim to find out about their opinion on implementing the process orientation concept, as well as the key factors that affect its effectiveness.

The following research hypotheses are derived: 
Kahrović I.E., Krstić D.B.: The Effects of Business Process Management on...

H1: Higher level of business process orientation positively influences performances of the process of supplying necessary inputs $\left(P_{1}\right)$,

H2: Higher level of business process orientation positively influences performances of the process of creation and manufacturing of products $\left(P_{2}\right)$,

H3: Higher level of business process orientation positively influences performances of the process of selling products and marketing activities $\left(P_{3}\right)$,

H4: Higher level of business process orientation positively influences performances of the product/service delivery process $\left(P_{4}\right)$,

H5: Higher level of business process orientation positively influences performances of the process of providing after-sales services to consumers $\left(P_{5}\right)$.

\subsection{Method}

For realizing the empirical research, the authors developed a questionnaire. It comprised 35 questions on BPO elements and performances of business processes. The questions were distributed across the two domains of questions presented in the theoretical part of the paper.

The first group of questions refers to BPO, as follow: process acceptance (definition and documentation) - PROCA (4 questions), process management and measurement - PROCM (3 questions) and process oriented organizational design - PROCD (3 questions).

Second group of questions refers to performances of identified business process: performances of the process of supplying necessary inputs - PERF1 (5 questions), performances of the process of creation and manufacturing of products - PERF2 (5 questions), performances of the process of selling products and accompanying marketing activities - PERF3 (5 questions), performances of the product delivery process - PERF4 (5 questions) and performances of the process of providing after-sales services to customers - PERF5 (5 questions).

Each question describes a specific business process orientation characteristic or business practice considered important within each domain. All responses in the survey pertaining to both dependent and independent variables are measured on five-point Likert scale from 1 to 5 (agreement scale: 1=strongly disagree, 2=disagree, 3=neither agree nor disagree, 4=agree, 5=strongly agree).

\subsection{Participants}

Questionnaires were sent to CEOs or senior management in 300 most profitable companies in Serbia. A total of 120 companies responded. The most common sort of business in the data set is Manufacturing (41.2\%). It is followed by 
Kahrović I.E., Krstić D.B.: The Effects of Business Process Management on...

Construction (13.7\%), Trade (11.9\%), Transport (7.2\%), Catering industry (6.4\%), while $19.6 \%$ of the companies were involved in other sorts of business.

\subsection{Data Analysis}

Data gathered by the questionnaire survey method were analysed in a few stages and utilizing various statistical methods. We used the statistical package SPSS 17.0 to run a series of data reduction tests. In the first place, validity analysis was conducted and research instrument validity checked. Content validity was ensured by using the items adapted from the literature, and by conducting the empirical study. Convergent validity was tested using explanatory factor analysis in order to uncover the key structure of a relatively large set of variables, which were utilized under the a priori assumption that any factor may be associated with any indicator (Hair, 2006). Second, reliability analysis was conducted using Cronbach's $\alpha$ coefficients that indicate internal consistency of the items used for calculating scales (Feldt \& Kim, 2008). Third, primary data were submitted to descriptive data analysis and correlation analysis in order to check for small, moderate and strong correlations between elements of business process management and performances of business processes (Cohen, Cohen, \& Aiken, 2013). And fourth, the effects of the elements of BPM on performances of business processes are examined using multiple regressions (Tabachnick \& Fidell, 2007).

\section{Research results and discussion}

\subsection{Results of Validity analysis}

First of all, research instrument validity was checked. Two parts of construct validity were analysed: content validity and convergent validity. Content validity was set up by study conducting literature review, then academic researchers and practitioners by realizing empirical research. The questionnaire was structured in such manner so that the key elements of business process management in Serbian companies can be analysed. Explanatory factor analysis was realized to test convergent validity for BPO elements and performances of the identified business processes. Firstly, we analysed the items measuring the BPO elements. As this construct had been tested widely, the results demonstrated in Table 2 were anticipated as three factors emerged, each reproducing one aspect of BPO (process acceptance, proca1-proca4; process management and measurement, procm5-procm7; process oriented organizational design, procd8-procd10). 
Kahrović I.E., Krstić D.B.: The Effects of Business Process Management on...

Table 2. Rotated factor Matrix for BPM elements

\begin{tabular}{|c|c|c|c|}
\hline & \multicolumn{3}{|c|}{ Factor } \\
\hline & 1 & 2 & 3 \\
\hline procd2 - The role of process owner is defined in our organization & ,883 & & \\
\hline procd1 - The organizational structure is derived from the business process & ,679 & & \\
\hline procd3 - Process teams exist within the enterprise & ,670 & & \\
\hline $\begin{array}{l}\text { proca2 - Process terms such as input, output, process and process owner are used in } \\
\text { conversation in the organization }\end{array}$ & & 880 & \\
\hline proca3 - Process within an organization are defined and documented & & ,862 & \\
\hline $\begin{array}{l}\text { proca1 - Managers and employees distinguish business process from functional } \\
\text { department }\end{array}$ & & ,627 & \\
\hline proca4 - The average employee views the business as a series of linked processes & & ,514 & \\
\hline procm1 - Management attaches a lot of importance to development of BPO & & & ,778 \\
\hline procm3 - Management is actively involved in process improvement effort & & & ,573 \\
\hline $\begin{array}{l}\text { procm2 - Practice of measuring, monitoring and controlling of business process } \\
\text { performance is implemented in the enterprise }\end{array}$ & & & ,546 \\
\hline
\end{tabular}

Source: Prepared by the authors (SPSS Statistics)

Considering that the analysis resulted in three factors, which structure is identical to the theoretical assumptions, the factor analysis confirmed that the theoretically conducted grouping of variables is empirically acceptable. Below are the results of the analysis, which shows the details of empirical grouping of individual particles of the questionnaire into factors. The analysis also points that statistical prerequisites for the exploratory factor analysis are met, since the Kaiser-MeyerOlkin (KMO) Measure of Sampling Adequacy exceeds $0.60(0,720)$ and Bartlett's Test of Sphericity is statistically significant.

Empirical analysis confirmed that the extracted factor explains a significant part of the variance of individual items, which is demonstrated by individual factor loadings (which typically exceed the experiential limit value of 0.5). The extracted factor explains $86.07 \%$ of the total variance, which is considered satisfactory for its values to be used in further statistical analysis.

Our analysis continued with the performances of the identified business process. The factor analysis of the items revealed five factors (Table 3). Each factor is representing one identified business process with accompanying performances (performances of the process of supplying necessary inputs, perf1.1 - perf1.5; performances of the process of creation and manufacturing of products, perf2.1 perf2.5; performances of the process of selling products and accompanying marketing activities, perf3.1 - perf3.5; performances of the product/service delivery process, perf4.1 - perf4.5; performances of the process of providing 
Kahrović I.E., Krstić D.B.: The Effects of Business Process Management on...

after-sales services to consumers, perf5.1 - perf5.5). The analysis points that statistical prerequisites for the exploratory factor analysis for performances of the identified business processes are met, since the Kaiser-Meyer-Olkin (KMO) Measure of Sampling Adequacy exceeds $0.60(0,815)$ and Bartlett's Test of Sphericity is statistically significant $(p=0.000)$.

Table 3. Rotated factor Matrix for Performances of Identified Business Processes

\begin{tabular}{|c|c|c|c|c|c|}
\hline & & & Factor & & \\
\hline & 1 & 2 & 3 & 4 & 5 \\
\hline perf5.1 - Reducing the product assembly costs & 0,982 & & & & \\
\hline perf5.2 - Reducing the rate of losing customers & 0,879 & & & & \\
\hline perf5.3 - Reducing the number of customer complaints & 0,773 & & & & \\
\hline $\begin{array}{l}\text { perf5.5 - Increase in the level of customer perceived value of } \\
\text { a product }\end{array}$ & 0,670 & & & & \\
\hline $\begin{array}{l}\text { perf5.4 - Reducing the rate of products returned by } \\
\text { customers }\end{array}$ & 0,568 & & & & \\
\hline perf2.3 - Planned production cycle time & & 0,776 & & & \\
\hline perf2.5 - Increasing number of product lines & & 0,665 & & & \\
\hline perf2.4 - Achieved production cycle time & & 0,661 & & & \\
\hline $\begin{array}{l}\text { perf2.1 - Minimizing the time from identification of customer } \\
\text { needs to product development }\end{array}$ & & 0,538 & & & \\
\hline $\begin{array}{l}\text { perf } 2.2 \text { - Reducing the time required to produce a new } \\
\text { product }\end{array}$ & & 0,532 & & & \\
\hline perf3.3 - Increase in the number of customers/buyers & & & 0,863 & & \\
\hline perf3.4 - Improving the brand image & & & 0742 & & \\
\hline perf3.2 - Increase in the number of new markets (\%) & & & 0,742 & & \\
\hline $\begin{array}{l}\text { perf3.5 - Increase in the number of ideas for new products } \\
\text { suggested by customers/buyers }\end{array}$ & & & 0,739 & & \\
\hline perf3.1 - Reducing the cost of market research (\%) & & & 0,568 & & \\
\hline perf4.5 - Reduction of insurance costs (\%) & & & & 0,641 & \\
\hline perf4.3 - Increase in the number of wholesale shops & & & & 0,623 & \\
\hline perf4.4 - Transportation cost reduction & & & & 0,606 & \\
\hline perf4.1 - Increase in the number of distribution channels & & & & 0,599 & \\
\hline perf4.2 - Increase in the number of retail shops & & & & 0,484 & \\
\hline perf1.3 - Procurement cost reduction & & & & & 0,784 \\
\hline perf1.1 - Increasing number of offers from suppliers & & & & & 0,795 \\
\hline $\begin{array}{l}\text { perf1.2 - Providing required quantities/types of materials on } \\
\text { time }\end{array}$ & & & & & 0,781 \\
\hline $\begin{array}{l}\text { perf1.5 - Increasing value share of purchases from certified } \\
\text { suppliers in total purchase value }\end{array}$ & & & & & 0,544 \\
\hline $\begin{array}{l}\text { perf1.4 - Increasing value share of purchases from individual } \\
\text { suppliers in total purchase value }\end{array}$ & & & & & 0,434 \\
\hline
\end{tabular}

Source: Prepared by the authors (SPSS Statistics) 
Kahrović I.E., Krstić D.B.: The Effects of Business Process Management on...

For the second group of factors, factor loadings appropriately represent the theoretically "logical" group of items, related to business process orientation (see Table 3). The factor explains $87.67 \%$ of the total variance, which is a satisfactory result, enabling the use of factor score in further statistical analysis.

\subsection{Results of Reliability analysis}

Cronbach's Alpha coefficients is widely used as a measure of reliability. Reliability analysis was realized and Cronbach's Alpha coefficients were calculated. In assessing the scale reliability, we were led by recommendations that internal consistency coefficients of 0.60 or higher are considered to demonstrate satisfactory reliability. As it can be seen in next five tables, all Cronbach's Alpha coefficients for the elements of BPM and performances of business processes were above the minimum acceptable level of 0.60 , which suggested that the item scales were reliable.

\subsection{Results of Correlation analysis}

Further analysis will determine whether there is a correlation between the values of factor scores for the previously described factors. It indicates that the theoretically set model is relevant. The results are correlation matrix, shown in next five tables, which demonstrates that all latent variables are mutually correlated, with the Pearson's correlation coefficient statistically significant, which demonstrates the existence of statistically relevant relationships.

Most coefficients (Table 4) demonstrated that there was a moderate correlation between items representing elements of BPO and performances of the process of supplying necessary inputs. The highest correlation coefficient values between individual items were as follows: procm2 and perf1.5 $(p=0.628, p<0.05)$, procm3 and perf1.5 $(p=0.625, p<0.01)$. Significant relationship was determined in the following few items: procm2 and perf1.1 $(p=0.576, p<0.01)$, procm3 and perf1.2 $(p=0.560, p<0.01)$, procd1 and perf1.5 $(p=0.590, p<0.01)$, procd2 and perf1.5 $(0.583, p<0.01)$. Also, the results clearly emphasize that there is a highest correlation coefficient between process management and measurement practices (PROCM) and the increasing number of offers from suppliers (perf1.1, $p=0.617$ ) or increasing value share of purchases from certified suppliers in total purchase value. (perf1.5, $\mathrm{p}=0.684$ ). Therefore, we confirm the hypothesis $\mathrm{H} 1$. 
Kahrović I.E., Krstić D.B.: The Effects of Business Process Management on...

Table 4. Descriptive statistics and Pearson correlations

(Dependent variable: performances of the process of supplying necessary inputs)

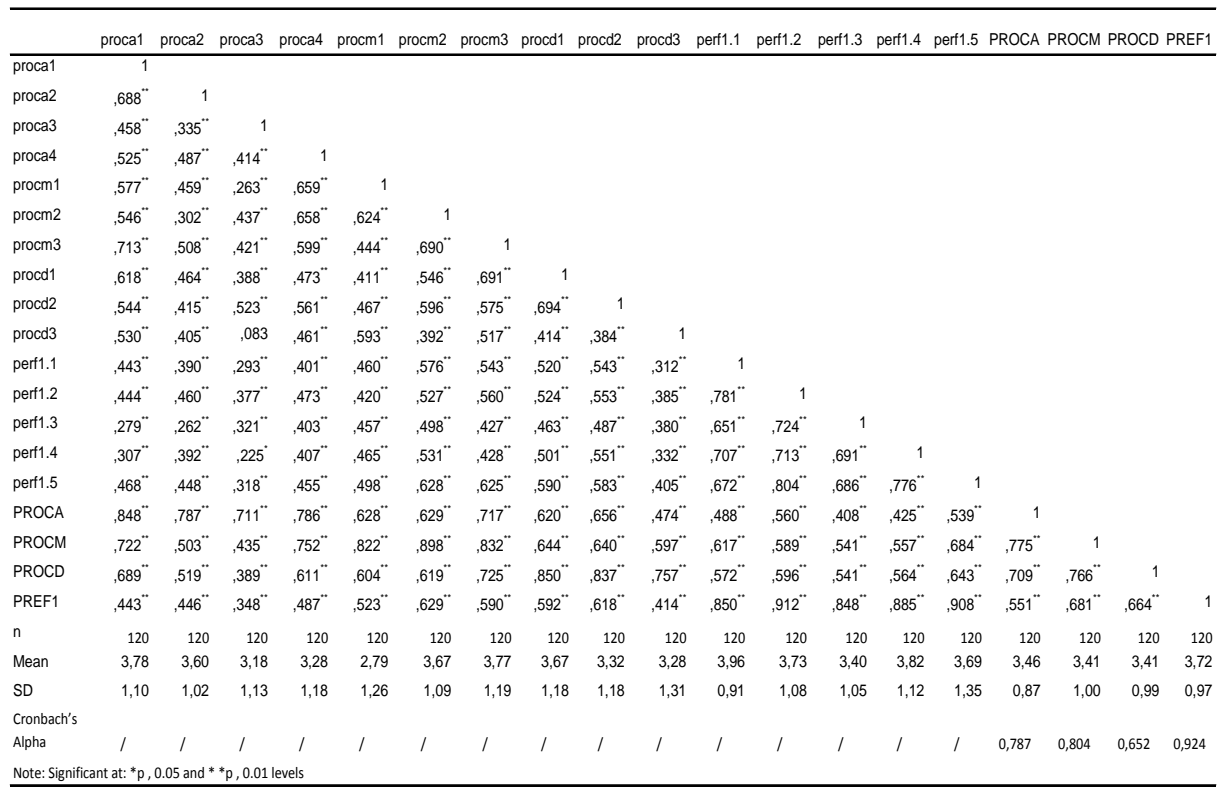

Note: Significant at: $* \mathrm{p}, 0.05$ and $* * \mathrm{p}, 0.01$ levels

Source: Prepared by the authors (SPSS Statistics)

Also, there was a moderate and significant correlation between items representing elements of BPO and performances of the process of creation and manufacturing of products (Table 5). The results clearly emphasize that there is a highest correlation coefficient between few variables. Namely, practice of measuring, monitoring and controlling of business process performance (procm2) have influence on achieved production cycle time (perf2.4, $p=0.602, p<0.01$ ). Also, there is a positive correlation between existing of process oriented organizational structure (procd1) and specified persons (procd2) responsible for realization of this business process $(p=0.631$ and $p=0.662, p=0.01$, respectively). Therefore, we confirm the hypothesis that higher level of business process orientation positively influences performances of the process of creation and manufacturing of products $(\mathrm{H} 2)$. 
Kahrović I.E., Krstić D.B.: The Effects of Business Process Management on...

Table 5. Descriptive statistics and Pearson correlations

(Dependent variable: performances of the process of creation and manufacturing of products)

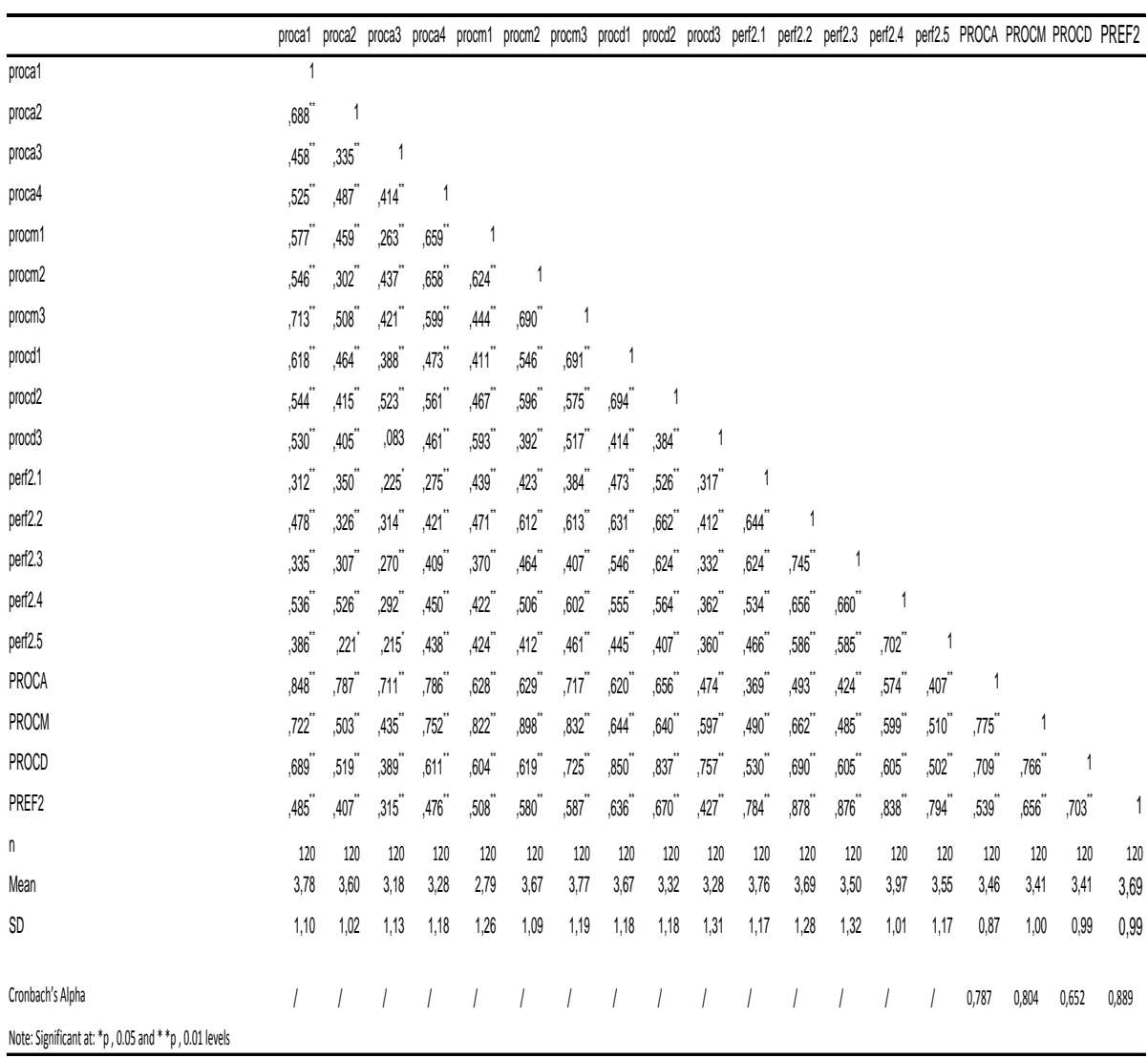

Source: Prepared by the authors (SPSS Statistics)

Significant relationship between elements of BPM and performances of the process of selling products and accompanying marketing activities (Table 6) were determined in the subsequent items: procm2 and perf3.3 $(p=0.595, p<0.01)$, procd 2 and perf3.4 $(p=0.590, p<0.01)$, proca1 and perf3.3 $(p=0.586, p<0.01)$. The results clearly emphasize that process management and measurement (PROCM) practices are positively related to and have a significant impact in the number of customers/buyers (perf3.3, $p=0.636, p<0.01$ ), improving the brand image (perf3.4, $p=0.668, p<0.01$ ), and the number of ideas for new products suggested by customers/buyers (perf3.5, $p=0.608, p<0.01$ ). Based on that, we confirm the hypothesis that higher level of business process orientation positively influences performances of the process of selling products and marketing activities (H3). 
Kahrović I.E., Krstić D.B.: The Effects of Business Process Management on...

Table 6. Descriptive statistics and Pearson correlations

(Dependent variable: performances of the process of selling products and accompanying marketing activities)

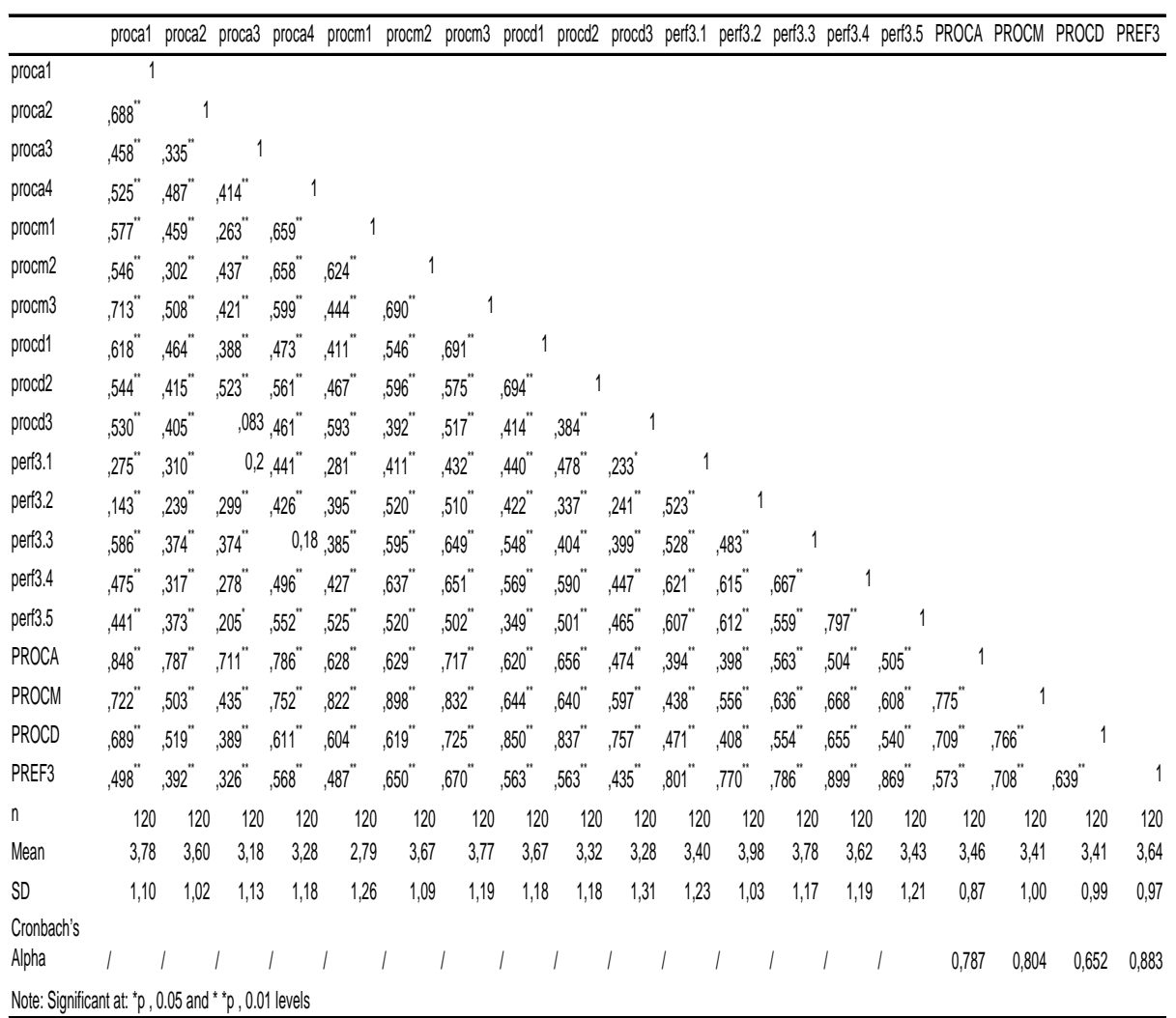

Source: Prepared by the authors (SPSS Statistics)

Most coefficients showed that there was a moderate correlation between items representing elements of BPM and performances of the product delivery process (Table 7). The highest correlation coefficient values between individual items were as follows: procm2 and perf4.5 $(p=0.638, p<0.05)$, procm3 and perf4.5 $(p=0.638, p<0.05)$. Stronger relationship was determined in the following items: procm1 and perf4.4 $(p=0.546, p<0.05)$, proca4 and perf4.4 $(p=0.559, p<0.05)$, proca2 and perf4.4 $(p=0.569, p<0.05)$.

Also, the results emphasize that process oriented organizational design (PROCD) practice is positively connected to and have a significant impact on transportation cost reduction (perf4.4, $\mathrm{p}=0.565, \mathrm{p}<0.01$ ) and reduction of insurance costs (perf4.5, $p=0.578, p<0.01$ ). We confirm the hypothesis that higher level of 
Kahrović I.E., Krstić D.B.: The Effects of Business Process Management on...

business process orientation positively influences performances of the product/service delivery process $(\mathrm{H} 4)$.

Table 7. Descriptive statistics and Pearson correlations

(Dependent variable: performances of the product delivery process)

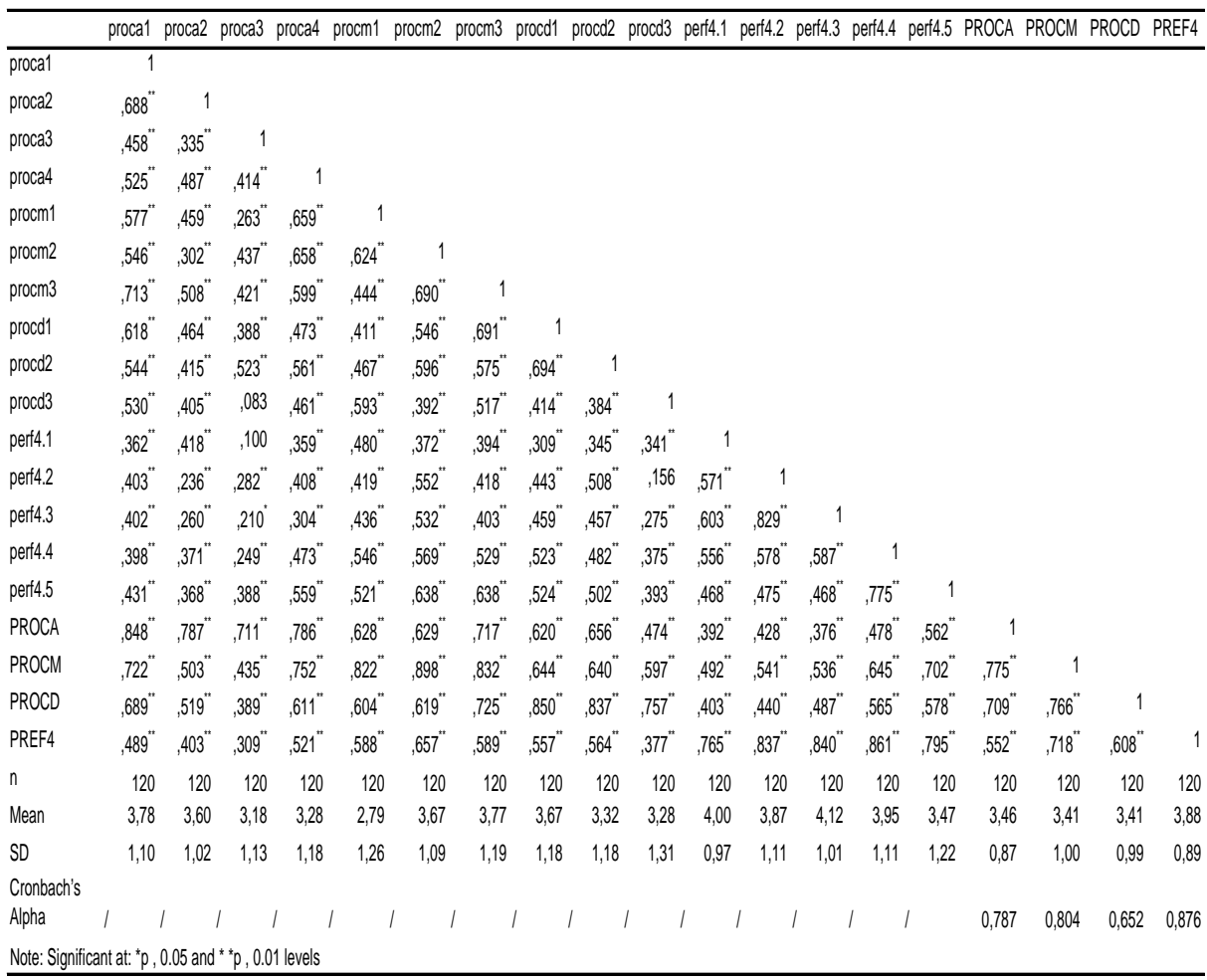

Source: Prepared by the authors (SPSS Statistics)

Between items representing elements of BPM and performances of and the process of providing after-sales services to customers most coefficients demonstrated that there was a moderate and strong correlation. The highest correlation of coefficient values between individual items was as follows: proca4 and perf5.1 $(p=0.688, p<0.05)$, procm2 and perf5.1 $(p=0.629, p<0.05)$, procm3 and perf5.1 $(p=0.638, p<0.05)$. Strong relationship was determined in the following items: procm 1 and perf5.1 $(p=0.570, p<0.05)$, procm2 and perf5.2 $(p=0.546, p<0.05)$, procm3 and perf5.2 $(p=0.552, p<0.05)$. Also, there is a highest correlation coefficient between PROCM and perf5.2 (0.626, $p<0.05)$, PROCD and perf5.1 $(p=0.655, p<0.05)$. The results show that process management and measurement practices (PROCM) are positively correlated to and have a 
Kahrović I.E., Krstić D.B.: The Effects of Business Process Management on...

significant impact on reducing the product assembly costs (perf5.1, $p=0.719$, $\mathrm{p}<0.01$ ). Therefore, it is possible to confirm the hypothesis H5.

Table 8. Descriptive statistics and Pearson correlations

(Dependent variable: performances of and the process of providing after-sales services to customers)

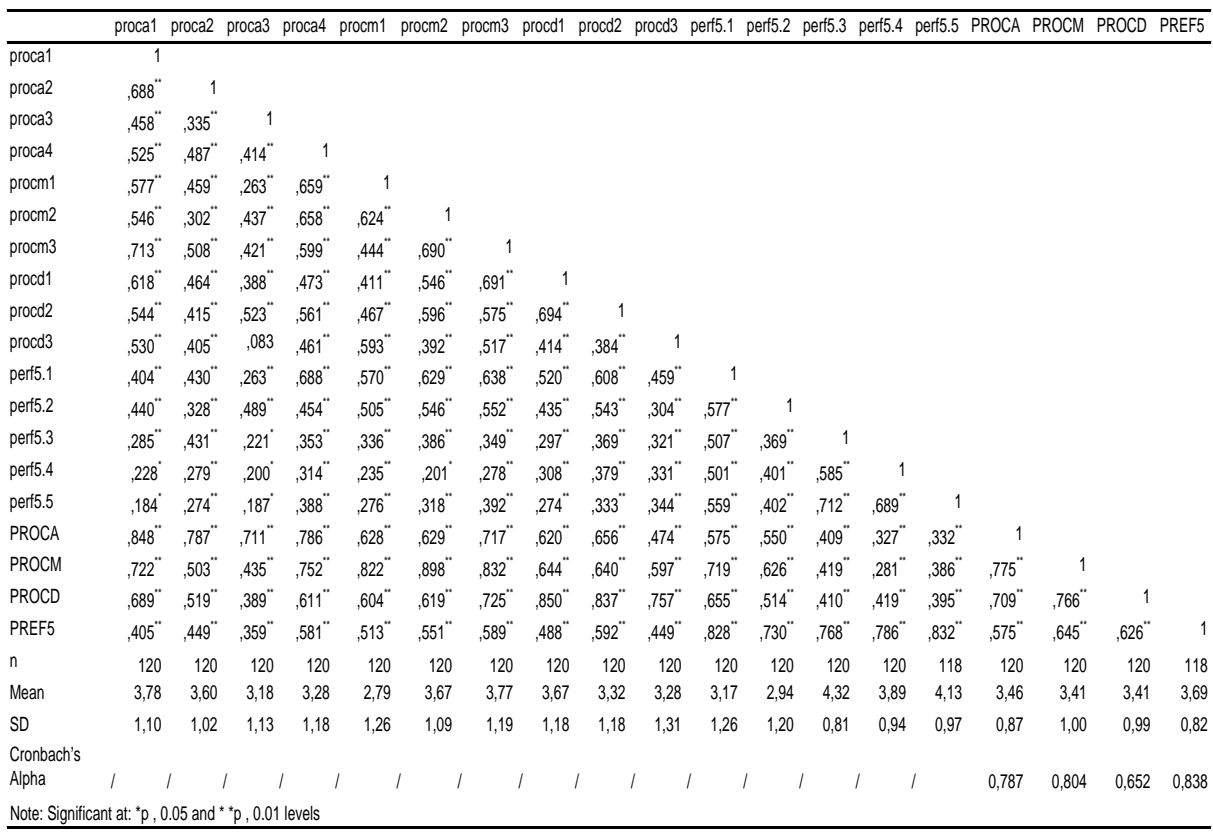

Source: Prepared by the authors (SPSS Statistics)

\subsection{Results of Regression analysis}

The effects of the BPM elements on performances of business processes are examined using multiple regressions. In the regression models, all entered variables have $p$-values 0.05 and below. The resulting models consist of performances of business processes as a function of the three elements of business process orientation. The results of the multiple regression are presented in Table 9.

In order to determine whether elements of BPM affect performances of identified business process, we used a simple and multiple linear regression. Relying on formula $\mathrm{N} \geq 50+8 \mathrm{~m}$ ( $\mathrm{N}$-number of observations, and $\mathrm{m}$ is the number of independent variables, namely the number of predictors), sufficient sample for our multiple model where we have three predictors $N=74$. For simple linear regression sufficient sample has $N=107(m+N \geq 104)$ (Tabachnick \& Fidell, 2007). In the single linear regression, all predictors showed a significant impact 
Kahrović I.E., Krstić D.B.: The Effects of Business Process Management on...

on the five dependent variables. How did we get such a result, if the multi-model entered all the predictors. The coefficient of determination $\left(R^{2}\right)$ is a relatively high range from 0.18 to 0.32 . Well, at least it explained variance of $18 \%$ and up $32 \%$.

Table 9. Multiple regression for elements of BPM and performances of business processes

\begin{tabular}{|c|c|c|c|c|c|}
\hline \multirow[b]{2}{*}{ Elements } & \multicolumn{5}{|c|}{ Dependent variables } \\
\hline & PERF1 & PERF2 & PERF3 & PERF4 & PERF5 \\
\hline Process acceptance & ,035 &,- 071 & ,105 & ,054 & ,111 \\
\hline Process management and measurement & $0,446^{\star}$ & $0,319^{*}$ & $0,532^{\star \star}$ & $0,640^{\star \star}$ & $0,349^{\star \star}$ \\
\hline Process oriented organizational design & $0,346^{\star \star}$ & $0,508^{\star \star \star}$ & $0,227^{*}$ & ,156 & $0,275^{\star}$ \\
\hline$R^{2}$ & 0,25 & 0,28 & 0,32 & 0,27 & 0,18 \\
\hline $\mathrm{F}$ & $40,87^{\star \star}$ & $42,9^{\star \star}$ & $35,9^{\star \star}$ & $28,9^{\star \star}$ & $32,4^{\star \star}$ \\
\hline $\mathrm{N}$ & 120 & 120 & 120 & 120 & 120 \\
\hline \multicolumn{6}{|c|}{$\begin{array}{l}\text { Notes: Significant at: }{ }^{*} \mathrm{p}-0.05,{ }^{*} \mathrm{*} p-0.01 \text { and } * * * \mathrm{p}-0.001 ; \text { standardized regression coefficients are } \\
\text { reported; all tests are two tailed }\end{array}$} \\
\hline
\end{tabular}

Source: Prepared by the authors (SPSS Statistics)

The results of the multiple regression of performances of the process of supplying necessary inputs on the process orientation constructs are presented in the first data column of Table 9. Process management and measurement is positively associated with performances of supplying necessary inputs $(p<0.05)$. The analysis shows that the more a firm applied process oriented organizational design is in line with the business process management technique, the higher is the performances of this business process $(p<0.01)$. Process management and measurement process oriented organizational design jointly explained $25.0 \%$ of the PERF1.

The second data columns of Table 9 pertain to the effects of performances of the process of creation and manufacturing of products on the business process orientation elements. Process management and measurement is positively associated with performances of the process of supplying necessary inputs $(\mathrm{p}<0.05)$. The analysis show that the more a firm applied process oriented organizational design is in line with the business process approach, the higher is the performances of this business process $(p<0.001)$. They explained $28.0 \%$ of the PERF2. 
Kahrović I.E., Krstić D.B.: The Effects of Business Process Management on...

The results of the multiple regression of performances of the process of selling products and accompanying marketing activities on the process orientation constructs are presented in the third data column of Table 9. Process management and measurement is positively associated with performances of the process of selling products and accompanying marketing activities $(p<0.01)$. The empirical data indicate that the more a company applied process oriented organizational design is in line with the BPO, the higher is the performances of this business process $(p<0.05)$. They explained $32.0 \%$ of the PERF3.

Results for the analysis of performances of the product delivery process on the business process orientation are presented in the fourth data column of Table 9, indicating that a process management and measurement is positively associated with performances of the product delivery process $(p<0.01)$. Process management and measurement explained $27.0 \%$ of the PERF4.

The results of the multiple regression of performances of and the process of providing after-sales services to customers on the process orientation constructs are presented in the fifth data column of Table 12. Process management and measurement is positively associated with performances of the product delivery process $(p<0.01)$. The analysis indicates that the more a company applied process oriented organizational design is in line with the process approach, the higher is the performances of this business process $(p<0.05)$. They are explained $18 \%$ of the PERF 5.

Our research has empirically supported some earlier assumptions regarding the leading role of financial and non-financial indicators and the lagging role of financial indicators. McCormack and Johnson (2001) recognized the link between process-oriented organizations and the business performance improvement. Their results provide evidence that BPM helps companies to break down the functional silos that exist in most organizations and enhance esprit de corps.

Škrinjar et al. (2008) verified this interconnectedness in transition economy with more detailed specification of organizational performance that included both financial and non-financial performance indicators. Furthermore, it has been shown that there is a strong direct impact of BPM on non-financial performance Also, it has been shown that BPM has a strong indirect impact on financial performance through non-financial performance.

Research findings of Hernaus et al. (2012) revealed that the existence of business process goals and policies in general, and improvement goals and plans in particular, foster process performance measurement practices.

Kohlbacher and Reijers (2013) in their empirical study revealed that process performance measurement, a process oriented organizational structure, the application of continuous process improvement methods, and - in particular - a culture in line with the process approach, are significantly and positively associated with organizational performance. 
Kahrović I.E., Krstić D.B.: The Effects of Business Process Management on...

\section{Conclusion and recommendations for managers}

The main aim of this paper was to determine whether higher level of business process management leads to higher performances of business process. The data from the empirical research, which were subjected to statistical techniques, confirmed that statement. Namely, hypotheses that process acceptance (documentation and definition), process management and measurement, and process oriented organizational design related to the $P_{1}, P_{2}, P_{3}, P_{4}$ and $P_{5}$ process are significantly and positively associated with performances of identified business process, such as: the process of supplying necessary inputs, the process of creation and manufacturing of products, the process of selling products and accompanying marketing activities, the process of product/service delivery, and the process of providing after-sales services to customers.

The management of companies operating in Serbia needs even more to recognize the advantages of process oriented management for improving the economic efficiency. It is necessary that the company management fully understands the benefits that process-oriented management of the company brings in terms of business focus, structural elements, the performance measurement system and employee reward systems.

Limitation of this empirical research is the fact that it was conducted only in Serbia, so a comparative analysis of practices in other countries, on the basis of the selected indicators, needs to be done in the future research. Regardless of the constructs of the model and their validity, the objectivity of responses has to be taken into account. Since CEOs or senior management perceptions were analysed by the questionnaire, it is possible that the managers evaluation was subjective. Namely, the survey respondents sometimes perceive the situation in their companies to be better than it usually is.

It is necessary to understand and implement process management principles consistently in order to receive benefits from the business process management approach, which then leads to the improved business performance. Managers of a large number of companies need to understand the principles of the processbased management and thus manage the business processes, performances in line with the staged approach, i.e. phases such as: planning, measuring, analysing and improving business process performances.

\section{References}

APQC International Benchmarking Clearinghouse. (2008). Process Classification Framework, Houston, TX: APQC

Bosilj-Vukšić, V., Hernaus, T., \& Kovačić, A. (2008). Upravljanje poslovnim procesima organizacijski i informacijski pristup. Zagreb, Hrvatska: Školska knjiga. 
Kahrović I.E., Krstić D.B.: The Effects of Business Process Management on...

Bryne, J. A. (1993). The Horizontal Corporation. Business Week, Dec. 13, 76-81.

Cohen, J., Cohen, P., West, S. G., \& Aiken, L. S. (2013). Applied Multiple Regression/Correlation Analysis for the Behavioural Sciences. Mahwah, NJ: Lawrence Erlbaum Associates, Inc.

Crosetto, G., \& Macazaga, J. (2005). The Process-Based Organization - A Natural Organization Strategy, Amherst, MA: HRD Press.

Daft, R.L. (2007). Understanding the Theory and Design of Organizations. Manson, IA: Thomson South-Westeren.

Davenport, T. H., \& Short, J. (1990). The New Industrial Engineering: Information Technology and Business Process Redesign. Sloan Management Review, 31(4), 1127.

Davenport, T.H. (1993). Process Innovation: Reengineering Work through Information Technology. Boston, MA: Harvard Business School Press.

Dutta, S., \& Manzoni, J. F. (1999). Process Re-engineering, Organizational Change and Performance Improvement. London, UK: McGraw-Hill Publishing Company.

Galbraith, J.R. (2002). Designing Organizations: An Executive Guide to Strategy, Structure, and Process. San Francisco, CA: Jossey-Bass.

Gardner, R. (2004). The Process - Focused Organization. Milwaukee, WI: Quality Press.

Hair, J. F., Black, W. C., Babin, B. J., Anderson, R. E., Tathan, R. L. (2006). Multivariate Data Analysis, Upper Saddle River, NJ: Prentice-Hall.

Hammer, M. (1996). Beyond Reengineering: How the Process - Centred Organization Is Changing Our Work and Our Lives. New York, NY: Harper Collins Publishers.

Hammer, M. (2007) The process audit. Harvard Business Review, 85(4), 111-123.

Hammer, M. H., \& Champy, J. (1993). Reenginnering the Corporation: A Manifesto for Business Revolution. New York, NY: Harper Business.

Hammer, M., \& Stanton, S. (1999). How Process Enterprises Really Work. Harvard Business Review, 77(6), 108-118.

Harmon, P. (2003). Business Process Change: A Manager's Guide to Improving, Redesigning, and Automatic Processes. San Francisco, CA: Morgan Kaufmann Publishers.

Harrington, J. (2006). Process Management Excellence - The Art of Excelling in Process Management. San Francisco, CA: Paton Press LLC.

Hernaus, T., Pejić-Bach, M., \& Bosilj-Vukšić, V. (2012). Influence of strategic approach to BPM on financial and non-financial performance. Baltic Journal of Management, 7(4), 376-396. doi: 10.1108/17465261211272148

Keen, P.G. (1997). The Process Edge-Creating Value Where It Counts. Boston, MA: Harvard Business School Press.

Kim, S., Feldt, L. S. (2008). A Comparison of Tests for Equality of Two or More Independent Alpha Coefficients, Journal of Educational Measurement, 45(2), 179193.

Kohlbacher, M. (2008). Process Orientation of Manufacturing Companies. Paper presented at the GBDI Tenth International Conference, Las Vegas, NV.

Kohlbacher, M., \& Gruenwald, S. (2011). Process orientation: conceptualization and measurement, Business Process Management Journal. 17(2), 267-283. doi: 10.1108/14637151111122347

Kohlbacher, M., \& Reijers, H. A. (2013). The effect of process-oriented organizational design on firm performance. Business Process Management Journal, 19(2), 245-262. doi: 10.1108/14637151311308303 
Kahrović I.E., Krstić D.B.: The Effects of Business Process Management on...

Kuwaiti, M. E., Kay, J. (2000). The role of performance measurement in business process reengineering. International Journal of Operations \& Production Management, 20(12), 1411-1426. doi: 10.1108/01443570010353086

McCormack, K. P., \& Johnson, W. C. (2001). Business Process Orientation: Gaining the Ebusiness Competitive Advantage. Boca Raton, FL: St Lucie Press.

Neely, A. (1999). The performance measurement revolution: why now and what next? International Journal of Operations \& Production Management, 19(2), 205-228.

Neubauer, T. (2009). An empirical study about the status of business process management. Business Process Management Journal, 15(2), 166-183. doi: 10.1108/14637150910949434

Ostroff, F. (1999). The Horizontal Organization. New York, NY: Oxford University Press.

Porter, M.E. (1985). Competitive Advantage: Creating \& Sustaining Superior Performance. New York, NY: The Free Press.

Reijers, H. A. (2006). Implementing BPM systems: the role of process orientation. Business Process Management Journal, 12(4), 389-409. doi: 10.1108/14637150610678041

Rummler, G. A., Ramias, A., \& Rummler, R. A. (2009). White Space Revisited: Creating Value Through Process, San Francisco, CA: Pfeiffer.

Rummler, G., \& Brache, A. (1995). Improving Performance - How to Manage the Space on the Organization Charts. San Francisco, CA: Jossey Bass.

Skivington, J. E., \& Daft, R. L. (1991). A study of organizational framework and process modalities for the implementation of business-level strategic decisions. Journal of Management Studies, 28(1), 45-68.

Škrinjar, R., Bosilj-Vukšić, V., \& Indihar-Štemberger, M. (2008). The impact of business process orientation on financial and non-financial performance, Business Process Management Journal, 14(5), 738-754. doi: 10.1108/14637150810903084

Škrinjar, R., Bosilj-Vukšić, V., \& Indihar-Štemberger, M. (2010). Adoption of Business Process Orientation Practices: Slovenian and Croatian Survey. Business Systems Research, 1(1-2), 1-19.

Spanyi, A. (2008). More for Less: The Power of Process Management. Tampa, FL: Meghan-Kiffer Press.

Stalk, G., \& Black, E. (1994). The Myth of the Horizontal Organization. Canadian Business Review, 21(4), 26-29.

Sung, T. K., \& Gibson, D.V. (1998). Critical Success Factors for Business Reengineering and Corporate Performance: The Case of Korean Corporations. Technological Forecasting and Social Change, 58(3), 297-311.

Tabachnick, B. G., \& Fidell, S. L. (2007). Using Multivariate Statistics, Boston, MA: Pearson Education, Inc.

Tenner, A. R., \& DeToro, I. J. (2000). Process Redesign: The Implementation Guide for Managers, New York, NJ: Prentice Hall.

Weske, M. (2012). Business Process Management - Concepts, Languages, Architectures. Berlin, Springer. 